\title{
THE LOST FRESCO PAINTINGS OF THE INKERMAN CAVE CHURCHES (“TEMPLE WITH BAPTISTERY”, “CHURCH OF GEOGRAPHY”, MONASTERY OF ST. SOPHIA)
}

\author{
Yurii M. Mogarichev \\ Institute of Archaeology of Crimea of the Russian Academy of Sciences, Simferopol, Russian Federation; \\ Crimean Republican Institute of Postgraduate Pedagogical Education, Simferopol, Russian Federation
}

\begin{abstract}
Alena S. Ergina
Saint Petersburg State Academy of Arts and Design named after A.L. Stieglitz, Saint Petersburg, Russian Federation
\end{abstract}

Abstract. Introduction. Among the "cave towns" of Mountainous Southwestern Crimea, there are monuments located in the lower reaches of the Black River valley. There are no less than 9 rock-cut monastic complexes which include about 30 temples. Methods. Some churches of the $13^{\text {th }}-15^{\text {th }}$ centuries were decorated with fresco paintings. Today, frescoes have been preserved only in one church. Sources of the $18^{\text {th }}-20^{\text {th }}$ centuries indicate traces of paintings in more than five temples. Frescoes inside the "temple with baptistery", "Church of Geography (Eugraphy)", and the Monastery of St. Sophia have not survived. Archival materials that expose the plots and compositions are published in this work. Analysis. The frescoes of the "temple with baptistery" date back to the $13^{\text {th }}$ century. The Deesis composition is reconstructed in the apse conch. In the "Church of Geography (Eugraphy)" (the $13^{\text {th }}$ century), on each side of the throne, four figures of saints are depicted (The Holy Fathers composition). This is probably: John Chrysostom, Gregory the Theologian, Basil the Great, Cyril of Alexandria, Gregory of Nyssa, Athanasius of Alexandria and two more saints from among the Cappadocian Fathers. One of them is obviously St. Blaise. This painting in general terms repeats the traditional scheme of the lower register of the painting of the apses of the cave temples of the mountainous Crimea. The monastery of St. Sofia should be dated back to the $14^{\text {th }}-15^{\text {th }}$ centuries. During the period of the monastery's functioning, there were fresco paintings in the Main Church and Church no. 3, but all the attempts to attribute them were unsuccessful. Results. The analyzed frescoes show themes of Deesis and the Great Cappadocians. They are common for altar compositions in cave temples in South-West Crimea. In the interiors of the cave temples of Inkerman, there are: simple linear ornaments, complex plant reports, linear ornaments with complex weaving and plant elements.

Key words: Byzantium, Crimea, Inkerman, "cave towns", cave churches, frescoes.

Citation. Mogarichev Yu.M., Ergina A.S. The Lost Fresco Paintings of the Inkerman Cave Churches ("Temple with Baptistery", "Church of Geography", Monastery of St. Sophia). Vestnik Volgogradskogo gosudarstvennogo universiteta. Seriya 4. Istoriya. Regionovedenie. Mezhdunarodnye otnosheniya [Science Journal of Volgograd State University. History. Area Studies. International Relations], 2021, vol. 26, no. 6, pp. 31-51. (in Russian). DOI: https://doi.org/10.15688/jvolsu4.2021.6.3

\section{УТРАЧЕННЫЕ ФРЕСКОВЫЕ РОСПИСИ ПЕЩЕРНЫХ ЦЕРКВЕЙ ИНКЕРМАНА («ХРАМ С КРЕЩАЛЬНЕЙ», «ЦЕРКОВЬ ГЕОГРАФИЯ», МОНАСТЫРЬ СВ. СОФИИ)}

\section{Юрий Миронович Могаричев}

Институт археологии Крыма РАН, г. Симферополь, Российская Федерация; Крымский республиканский институт постдипломного педагогического образования, г. Симферополь, Российская Федерация 


\section{Алена Сергеевна Ергина}

Санкт-Петербургская государственная художественно-промышленная академия им. А.Л. Штиглица, г. Санкт-Петербург, Российская Федерация

Аннотация. Введение. В числе «пещерных городов» Горного Юго-Западного Крыма выделяются памятники, расположенные в низовьях долины р. Черной. Здесь известны не менее 9 скальных монастырских комплексов, в состав которых входили около 30 храмов. Mетоды. В XIII-XV вв. часть церквей была украшена фресковой росписью. Сегодня фрески сохранились только в одном храме. Источники XVIII-XX вв. отмечают следы росписей еще в пяти культовых сооружениях. В настоящей работе исследованы опубликованные и архивные материалы, которые могут пролить свет на сюжеты и композиции ныне не сохранившихся фресковых росписей «храма с крещальней», «церкви География (Евграфия)» и монастыря св. Софии. Анализ. Фресковые росписи «храма с крещальней» датируются XIII веком. В конхе апсиды реконструируется композиция Деисус. В «храме География (Евграфия)» (XIII в.) в апсиде, с каждой стороны от престола, изображены по четыре фигуры святителей (композиция «Служба святых отцов»). Вероятно, это: Иоанн Златоуст, Григорий Богослов, Василий Великий, Кирилл Александрийский, Григорий Нисский, Афанасий Александрийский, св. Власий и еще один не определяемый. Данная роспись повторяет в общих чертах традиционную схему нижнего регистра росписей апсид пещерных храмов Горного Крыма. Монастырь св. Софии следует датировать XIV-XV веками. Фресковые росписи в период функционирования монастыря имелись в Главном храме и церкви № 3. Но их атрибутировать сегодня невозможно. Результаты. В проанализированных фресковых росписях представлены сюжеты Деисус и «Служба святых отцов». Они являются обычными для алтарных композиций пещерных храмов Юго-Западной Таврики. В интерьерах пещерных храмов Инкермана выделяются: простые линейные орнаменты, сложные растительные рапорты, линейные орнаменты со сложным плетением и растительными элементами. Вклад авторов. Ю.М. Могаричевым подготовлены разделы об историографии и особенностях рассматриваемых памятников. А.С. Ергиной исследовались искусствоведческие аспекты.

Ключевые слова: Византия, Крым, Инкерман, «пещерные города», пещерные церкви, фрески.

Цитирование. Могаричев Ю. М., Ергина А. С. Утраченные фресковые росписи пещерных церквей Инкермана («храм с крещальней», «церковь География», монастырь св. Софии) // Вестник Волгоградского государственного университета. Серия 4, История. Регионоведение. Международные отношения. - 2021. T. 26, № 6. - C. 31-51. - DOI: https://doi.org/10.15688/jvolsu4.2021.6.3

Введение. В числе «пещерных городов» Горного Юго-Западного Крыма обращают на себя внимание памятники, расположенные в низовьях долины р. Черной (Балаклавский район г. Севастополя). Здесь выделяются: крепость Каламита; не менее 9 скальных монастырских комплексов, в состав которых входили около 30 храмов (рис. 1). Традиционно данные объекты именуются памятниками Инкерманской долины (Инкерманом).

История пещерных монастырей Инкерманской долины представляется так. Скорее всего, первые группы монахов или отдельные отшельники поселились в восточной части Загайтанской скалы (очевидно, не ранее XXI вв.). Вероятно, это были выходцы из Херсона. Постепенно монастырь расширяется, его иноками создаются новые скиты. XIII в. датируется «церковь География (Евграфия)». В этом же столетии отдельные отшельники поселяются в Каменоломном овраге и на Монастырской скале, где сооружается «храм с кре- щальней». B XIV-XV вв. формируется большинство комплексов на южном и западном обрывах Монастырской скалы и монастырь св. Софии. Выходцы из последнего основывают три скита на левом берегу р. Черной. Большое число культовых пещерных сооружений позволило Ю.М. Могаричеву предположить, что здесь в период развитого средневековья функционировал монашеский центр. Вероятно, ктиторами монастырей и церквей были люди, которые являлись частью элиты княжества Феодоро. После турецкого захвата Крыма в 1475 г. большая часть монастырей прекращает функционировать (подробно см.: [18, с. 630; 19, с. 68-88]).

Методы. Часть из церквей была украшена фресковой росписью. Сегодня фрески сохранились только в одном храме - церкви № 12 (по Ю.М. Могаричеву) в восточной части Загайтанской скалы [3; 4] ${ }^{1}$. Письменные источники и описания путешественников и исследователей XVIII-XX вв. указывают сле- 
ды росписей также: в базилике св. Георгия (Климента); «церкви География (Евграфия)»; «храме с крещальней»; монастыре св. Софии; церкви св. Георгия в Георгиевской (Крымской) балке. Авторами настоящей публикации были проанализированы фресковые росписи разрушенного при прокладке железной дороги к Севастополю во второй половине XIX в. храма скита св. Георгия в Георгиевской балке и базилики св. Георгия (Климента), которые были датированы первой - третьей четвертью XV в. [21]. В данной работе мы рассмотрим опубликованные и архивные материалы, которые могут пролить свет на сюжеты и композиции ныне не сохранившихся фресковых росписей «храма с крещальней», «церкви География (Евграфия)» и монастыря св. Софии.

Анализ. «Храм с крещальней» находится в южной части Монастырской скалы, выходящей в Гайтанскую балку или балку Первого мая, на высоте 25-30 м от подошвы скалы (рис. 1, 7; 2).

Упоминания о нем содержатся в ряде работ авторов первой половины XIX века. Д.М. Струков опубликовал схематический план церкви и краткое описание к нему $[25$, c. 27]. Небольшая информация и фотография памятника были представлены И.И. Толстым и Н.П. Кондаковым [27, с. 29]. А.Л. БертьеДелагард в своем обзоре церкви датировал ее «татарским временем». Была ученым упомянута и высеченная на стене усыпальницы надгробная надпись [2, с. 57-59]. В.В. Латышев опубликовал и перевел эту надпись «Упокоились рабы Божьи Аврамий сын (?) Афка комит месяца первого (?) дня... и Косьма Афка комит месяца марта 6329 (?)» [14, с. 40 $42 ; 15$, с. 151]. По мнению исследователя, она еще нуждалась в детальном рассмотрении. При этом он находил аналогии в написании фамилий и имен, встречающихся в «храме с крещальней», с именами из приписок XII$\mathrm{XV}$ вв. на полях Сугдейского синаксаря [14, c. 42]. Памятнику была посвящена отдельная статья В.Н. Чепелева [31]. Автор привел описание церкви, делая при этом свои замечания [31, с. 44]. Данная скальная церковь была обследована экспедицией Государственной академии истории материальной культуры (ГАИМК) в 1937 г., тогда она была расчищена, выполнены архитектурные обмеры (рис. 2). Н.И. Репников указывал на аналогии фресковым росписям памятника среди росписей храмов «Успения» и «Трех Всадников» (Эски-Кермен), которые он датировал XIII в. [24, л. 38]. В.Ф. Филиппенко на основании, как он ошибочно полагал, мнения В.В. Латышева, датировал церковь 832 г. [30, c. 114-115]. Ю.М. Могаричев относил время сооружения памятника к XIII-XIV вв. [17, с. $218 ; 18$, с. 11-12]. А.Ю. Виноградов предложил свой перевод упомянутой надписи: «Почили рабы Божьи Авраамий, ...первого разряда и комит, 8 числа первого месяца; и Ко[см]а, первого разряда и к[о]мит, 29 числа ...-го месяца», а памятник датировал XIII веком. По его мнению, погребенные в храме являлись его ктиторами [6].

В настоящее время церковь частично разрушена: сохранилась лишь апсида и северная часть с баптистерием (рис. 2). Храм был одноапсидный. Конха апсиды опирается на три высеченные в скале ниши. Алтарное полукружие имело двухступенчатый синтрон. В полу прямоугольное углубление $0,35 \times 0,32$ м для установки престола. Пол алтаря, как и примыкающий с севера жертвенник с нишей в стене, на 0,1 м выше остальной части памятника. По этой линии перепада пола проходила алтарная преграда. Последняя была высотой 1 м (по В.Н. Чепелеву). Из церкви в боковое помещение вел дверной проем размерами $1,6 \times 0,6$ м. Оно неправильной в плане формы, в углу его находится баптистерий с вырубленными в скале колоннами. Слева от последнего, в северной стене - проем, ведущий в усыпальницу. В ее полу высечена гробница, над которой вырублены гнезда для устройства деревянного перекрытия. На северо-восточной стене- ниша, рядом с которой и находится упомянутая шестистрочная греческая надпись.

В апсиде храма были росписи. Фресковые росписи имелись также в баптистерии и усыпальнице. В настоящее время они практически неразличимы. К сожалению, в историографии конца XVIII - XIX в. их подробное описание отсутствует. Д.М. Струков упоминает лишь следующее: «В алтаре у стены престол со впадиною вверху; над престолом по стене надпись и остатки фресковых изображений святых в облачениях» [25, с. 28]. На- 
ми в фонде изоизданий Российской государственной библиотеки были найдены акварельные листы, выполненные этим исследователем, с изображениями фрагментов интерьеров пещерной церкви, планов и деталей орнаментального убранства (рис. 3) [26, л. 12, 30].

А.Л. Бертье-Делагард отмечал: «Издали еще эта церковь узнается по остаткам живописи на своде, вблизи, однако ничего определенного нельзя разобрать и даже затрудняюсь назвать род краски: по-видимому, масляная по очень тонкому слою» [2, с. 57].

По сведению В.Н. Чепелева, росписи во второй половине 20-х гг. ХХ в. еще были различимы в углублении апсиды и на своде синтрона. Он указывает, что в колористическом решении стенописи преобладают буро-красные и серо-коричневые оттенки. В центре росписи - фигуры из Деисуса. На скамье сохранялся геометрический орнамент в виде параллельных зигзагообразных линий красного и черного цветов [31, с. 45]. По Н.И. Репникову: «Храм был оштукатурен и расписан фресками. Фрагменты закоптевших и затянутых “ямчугой”... стенописей имеются у вырубной гробницы, крещальни и в алтаре. На боковой стене алтаря контуры фигур святителей в рост, по низу панель из параллельных зигзагообразных линий красного и черного цветов, образующих треугольники. Стиль фрагментов живописи, равно орнаментальная панель, идентична росписям Эски-Кермена XIII в.» [24, л. 38].

Композиция Деисус традиционно во внутреннем пространстве храмов Горного Крыма занимает конху апсиды. Именно такое композиционное решение встречаем в церкви Успения (Эски-Кермен) [12, с. 42-50; 18, с. 46-49], близость стиля которой отмечал Н.И. Репников. Подобные аналогии видел и В.Н. Чепелев, однако сходство тот отмечал больше в орнаментальных мотивах: «Орнамент, цвет краски и техника исполнения идентичны». А вот аналогами иконографии сюжетов, по его мнению, могут являться как местные памятники (например, храмы Шулдана и Южного монастыря Мангупа), так и роспись в алтаре св. Леонарда в Массафра (Апулия) [31, с. 45-46].

Как видим, фресковые росписи «храма с крещальней» достаточно определенно могут датироваться XIII в. и традиционны для росписей пещерных церквей Таврики. В.Н. Чепелев даже предположил, что роспись церкви могла быть исполнена художниками, которые трудились в храме Успения и других подобных объектах Эски-Кермена [31, с. 45], что, правда, выглядит малореальным. Отметим, что А.Л. Бертье-Делагард, а вслед за ним и В.Н. Чепелев, указывали на следы наличия масляной краски [31, с. 45]. Если это верно, то можно предположить, что росписи могли подновляться в XVI-XVIII веках.

Храм Евграфия (География) находится в восточной части Монастырской скалы (рис. 1, 9). В начале XX в. церковь стала вновь действующей. Памятник в 1937 г. был засыпан грунтом, образовавшимся в результате строительства железнодорожной насыпи, и, соответственно, в настоящее время недоступен для осмотра и изучения. На карте русского штурмана И. Батурина (1773 г.) данное место обозначено как «храм География». Последующие исследователи предположили, что в карту вкралась ошибка и церковь была посвящена св. Евграфию [24, л. 40].

Д.М. Струков в работе «Древние памятники христианства в Тавриде» поместил схематичный план и краткие сведения о храме $[25$, с. 28$]$. Описания сохранявшихся тогда фресок опубликовали И.И. Толстой и Н.П. Кондаков [27, с. 29]. А.Л. Бертье-Делагард отмечал, что в архитектурном плане церковь похожа на соседнюю с базиликой св. Георгия часовню св. Мартина. На основании анализа живописи и планировки памятник был датирован им временем не ранее XVII века. Касаясь расположенной здесь надписи на задней стене апсиды, исследователь замечает, что та «оказалась весьма поздней и безграмотно написанной» и в ней нет точного указания на дату [2, с. 59-61]. В.В. Латышев, проанализировав надпись, датировал ее 1272 г. [14, c. $37-40 ; 15$, c. $150-151 ; 16$, c. $228-229]$. Церковь изучалась в 1937 г. сотрудниками Инкерманской экспедиции ГАИМК $[23$, л. $12-$ 13)] (рис. 4, 5). Ее детальное описание приведено также в «Материалах к археологической карте» Н.И. Репникова, который считал, что дата надписи (1272 г.) не вызывает сомнения и находится в полном соответствии с чертами росписей, композицией и стилем [24, л. 40-41]. Ю.М. Могаричев обобщил все имевшиеся материалы и присоединился к мнению исследователей, датировавших па- 
мятник XIII в. [18, с. 16-17]. А.Ю. Виноградов опубликовал следующий вариант перевода упомянутой надписи: «Моление раба Божьего Сотирика с женой его и детьми его. В 6781 году» (1272-1273 гг.) [7]. Н.В. Днепровский предположил, что название церкви «География» возникло в результате ошибочного понимания Батуриным греческого слова «агиография». Он также считает, что церковь следует датировать ранее утвердившегося в историографии мнения - XIII в. (см.: [10; 11; и др.]). Правда, последнее выглядит неаргументированным.

Как видим, вероятнее всего, пещерный «храм География (Евграфия)» был создан и расписан в третьей четверти XIII века. Очевидно, что упомянутый в посвятительной надписи Сотирик и его семья могли выступать ктиторами местного монастыря или данной церкви.

Что касается росписей, то И.И. Толстой и Н.П. Кондаков так их характеризуют: «По закруглению алтарной апсиды еще заметны фигуры восьми Святых в рост, от пола до потолка, с венцами, написанными желтою краской, а по сторонам венцов - надписи имен Святых белою, фон серый, краски грубые, малярные. Над алтарем, в виде запрестольного образа, поясное изображение, вероятно Спасителя; как у этого изображения, так и у других, уже невозможно разобрать ни ликов, ни цвета одежды, ни надписей - видны только отдельные греческие буквы» [27, с. 29].

А.Л. Бертье-Делагард приводит следующий обзор: «По закруглению алтарной апсиды еще заметны фигуры восьми святых (по четыре с каждой стороны престола) в рост, от пола до потолка, с венцами, писанными желтой краской, а по сторонам венцов надписи имен святых белой: все это на сером фоне и все масляными красками. Над алтарем, в виде запрестольного образа, только поясное изображение (вероятно, Спасителя), так как престол у стены не позволил писать до пола; вокруг венца нет надписи и, как у этого изображения, так и у других, уже невозможно разобрать ни ликов, ни одежд, ни надписей, видны только некоторые греческие буквы и лишь около второго лика справа можно, кажется, прочесть св. Власий; потолок в алтаре также был расписан, но тоже ничего нельзя разобрать» $[2$, с. 59$]$.
По Н.И. Репникову: «На потолке и в апсиде под побелками XX в. сохранились фресковые росписи. В алтаре фигуры восьми святителей в рост (по четыре с каждой стороны) на синем фоне в крещатых одеяниях с желтыми нимбами. Надписи имен белой краской. Непосредственно над престолом - младенец Христос в чаше. По низу изображений над престолом полоса серого цвета в черной кайме. В ней черными буквами, одновременная с росписью, греческая надпись» [24, л. 40-41].

Из отчета Инкерманской экспедиции ГАИМК 1937 г.: «Из побелки усматриваются фигуры восьми святителей в рост (по четыре с каждой стороны) на синем фоне в крещатых одеждах с желтыми нимбами. Надписи белой краской. Над престолом - изображение Христа в чаше. Надпись хорошей сохранности. Она датирована. По низу изображения над престолом длинная полоса серого цвета, обтянутая черною рамкой - “моление раба божьего Сотика с женою и детьми, лета 5780 (1272 г.)"» [23, л. 38].

В отличие от «храма с крещальней», Д.М. Струков сделал несколько подробных рисунков рассматриваемого памятника, в том числе запечатлел и остатки фресковых росписей $[26$, л. 9.3, 15, 16] (см., например, рис. 6-8). Обращает на себя внимание один лист, на котором данный храм обозначен как «церковь св. Николая» (рис. 9) [26, л. 9.3]. Все сохранившиеся к настоящему времени описания «церкви География» не упоминают об этом. Да и сам Д.М. Струков такое название поместил только на одном из рисунков памятника. Никто из исследователей храма, которые видели натурные росписи, не упоминают ни о наличии среди изображенных фигуры св. Николая (нет его и на рисунках самого Струкова), ни то, что церковь была освящена в честь этого святого. В 1905 г., при возобновлении, данный храм был освящен в честь Дмитрия Солунского $[28$, с. 92]. Как нам пояснил в устной беседе Н.В. Днепровский, он видел среди архивных материалов упоминание Д.М. Струкова, что так церковь якобы зовется местными жителями. Впрочем, это может быть и ошибкой художника.

Проанализировав рисунки Д.М. Струкова и материалы Инкерманской экспедиции ГАИМК 1937 г. (рис. 5), можно сделать вы- 
вод, что в «храме География (Евграфия)» на фресковых росписях с каждой стороны от престола помещены по четыре фигуры святителей (композиция «Служба святых отцов»). На основании имеющихся описаний и изображений можно предположить, что роспись апсиды рассматриваемого памятника содержала фигуры: Иоанна Златоуста, Григория Богослова, Василия Великого, Кирилла Александрийского, Григория Нисского, Афанасия Александрийского и еще двух святителей из числа Великих Каппадокийцев. Один из которых, если верно предположение А.Л. БертьеДелагарда, - св. Власий. Практически все упомянутые святые регулярно встречаются в храмовых росписях памятников византийского круга, в том числе и в Крыму, и являются наиболее прославленными и почитаемыми отцами Церкви. По сохранившимся фотографиям (рис. 5) видно, что фигуры святых отцов облачены в яркие белые саккосы с черными вставками темного орнамента омофора. Святители показаны в процессе богослужения. Основной белый тон доминирует и контрастирует с темными фрагментами орнамента и обеспечивает композиционное равновесие росписи апсиды пещерной церкви.

По рисункам Д.М. Струкова (рис. 6-9) видно, что в центре апсиды над престолом, вероятнее всего, был помещен образ Христа, предположительно Эммануила, являющийся центральным одиночным образом, который был отделен прямоугольной рамой.

Таким образом, роспись «храма География (Евграфия)» повторяет в общих чертах привычную схему нижнего регистра росписей апсид пещерных храмов горного Крыма, таких как: церковь № 12 (по Ю.М. Могаричеву) (Загайтанская скала, Инкерман) [4], храм Донаторов (округа Эски-Кермена) [18, с. 52-53], церковь Южного монастыря Мангупа [20, c. 50-52]. Там, по обе стороны от престола, также изображены в рост фигуры святителей «отцов церкви» в крестчатых одеждах и молитвенных позах.

Монастырь св. Софии. Памятник расположен на западной стороне Каменоломенного оврага (рис. 1, 3). В нем известно 22 помещения, в том числе 4 церкви (рис. 10).

Описания комплекса встречаются уже у П.С. Палласа [22, с. 51]. Упоминают о нем
Дж. Уэбстер [29, с. 135] и Ф. Дюбуа де Монпере [13, с. 243]. Дж. Уэбстер отмечал: «одна церковь... имеет форму греческого креста. В примыкающей комнатке все еще видны многочисленные знаки настенного письма. В обеих часовнях можно видеть как остатки штукатурки, так и грубые рисунки» [29, с. 135], Подобные сведения о монастыре оставил 3. Аркас. Он акцентировал внимание на входе в комплекс, главной церкви и часовни, при этом отметив: «В малой церкви (церковь № 3. - Ю. M., A. Е.) весь плафон и алтарь расписаны были масляными красками, но лики образов теперь различить невозможно; с боков заметны надписи на греческом языке, которые так истерлись, что прочесть невозможно» $[1$, с. 270$]$.

По Д.М. Струкову: «На противоположной стороне Инкермана, через Черную речку, на углу скалы, есть три долбленые храма. Один устроен в боку лестницы, ведущей во внутренность скалы: далее по коридору другой храм, имеющий потолок в форме правильного свода, квадратной формы, но, к сожалению, алтарь отвалился от скалы. Третий храм рядом с предыдущим к югу, меньший, имеющий престол у стены, под отверстием окна: жертвенник изсечен в нише северной стены алтаря, отделенного алтарною преградой, которая, судя по сохранившимся остаткам, была высотою 1 арш. 6 верш., с одним отверстием для входа в алтарь» [25, с. 29]. Д.М. Струковым были выполнены акварели ряда помещений этого комплекса. В частности, на одной из них художник изобразил план пещерного храма (церковь № 3, по Ю.М. Могаричеву (рис. 10,3)), сохранившиеся тогда надписи и фрагменты орнаментального убранства (рис. 11).

Подробно монастырь св. Софии обследовал А.Л. Бертье-Делагард [2, с. 70-72]. Ученый отмечает две церкви, а существование еще одной предполагает. Датирует он памятник XIV-XV вв., а надписи еще более поздним временем. Главный храм монастыря, по мнению А.Л. Бертье-Делагарда, - один из древнейших среди пещерных храмов Крыма. Исследователь со ссылкой на 3. Аркаса пишет об имевшихся когда-то росписях в главном храме и малой церкви, «но теперь уже ничего не заметно» [2, с. 70]. «На стенах цер- 
кви (№ 3. - Ю. М., А. E.) местами видны следы, кажется, фресковой живописи, но разобрать уже ничего невозможно» [2, с. 71].

В.В. Латышев кратко упомянул о наличии на стенах памятника ряда греческих надписей [14, с. 43-44].

Не обошли вниманием монастырь И.И. Толстой и Н.П. Кондаков, по данным которых главный «храм выдолблен в виде греческого креста, перекрытого плоским куполом», и является самым большим и роскошным из всех пещерных [27, с. 29-30], а «на стенах другой церкви местами видны следы фресковой живописи» [27, с. 30].

Н.И. Репников главную церковь датировал XIII, а «может быть даже XII в.» [24, л. 45]. Основываясь на исследованиях Инкерманской экспедиции ГАИМК 1937 г., он заметил: «В древности храм был расписан фресками. Осмотр фрагментов закопченных и покрытых солями извести стенописей определял их крупное художественное значение» [24, л. 45].

Комплекс монастыря св. Софии был проанализирован Ю.М. Могаричевым, который датировал его XIV-XV вв., хотя не исключил и XIII в. (см.: [18, с. 22-25], а также [9]).

Таким образом, вероятнее всего, монастырь св. Софии следует датировать XIV$\mathrm{XV}$ веками. Фресковые росписи в период функционирования монастыря имелись в Главном храме (№ 1) и церкви № 3. Но все попытки, а первую предпринял 3. Аркас в 1845 г., их каким-то образом атрибутировать, ввиду их практически полной утраты уже в то время, успеха не имели.

Результаты. В рассмотренных нами фресковых росписях пещерных церквей Инкермана выделяются сюжеты Деисус и «Служба святых отцов». Они являются традиционными для алтарных композиций пещерных храмов Юго-Западной Таврики. Это свидетельствует о доминировании византийских традиций фресковых росписей в стенописи скальных церквей средневеково- го Крыма XIII-XV веков. Отметим, что тип изображения святителей в подобном облачении, которые представлены фронтально в нижнем регистре апсид исследуемых памятников, уже в начале XII в. окончательно закрепляется в алтаре церквей византийского круга как композиция «Служба святых отцов». Примерами могут служить росписи в церкви монастыря Велюса (начало XI в.), монастыря Иоанна Златоуста в Кутсовендис на Кипре (конец XI - XII в.), церкви Пантелеймона в Нерези (XII в.), церкви монастыря Неофита около Пафоса на Кипре (XII в.) и др. [8, с. 245].

Исследуя графический материал, выполненный Д.М. Струковым (рис. 12), отметим, что в интерьерах пещерных храмов Инкермана представлены:

- простые линейные орнаменты, ленточные, отделяющие разные сюжеты в пределах одного архитектурного элемента;

- простые растительные рапорты, обрамляющие архитектурные элементы храма и отделяющие разные сюжетные композиции;

- сложные растительные рапорты, обрамляющие архитектурные элементы храма и отделяющие разные сюжетные композиции;

- линейные орнаменты со сложным плетением и растительными элементами.

Орнаментальное убранство подчеркивает как архитектурные элементы: колонны, арки, ниши, так и обрамляет сюжеты внутри больших архитектурных членений.

\section{ПРИМЕЧАНИЕ}

${ }^{1}$ А.Ю. Виноградов опубликовал выявленную в данной церкви надпись, датирующуюся началом $\mathrm{XIV}$ в. «Освящен божественный и всечестной храм иже во святых отца нашего архииерарха и чудотворца Николая, архиепископа Мир Ликийских, в келлии Ильи монаха, Иоанном Склиром [митрополитом] святейшей митрополии Херсона, 6 июня 6811 года» [5, с. 334-337]. 


\section{ПРИЛОЖЕНИЕ}

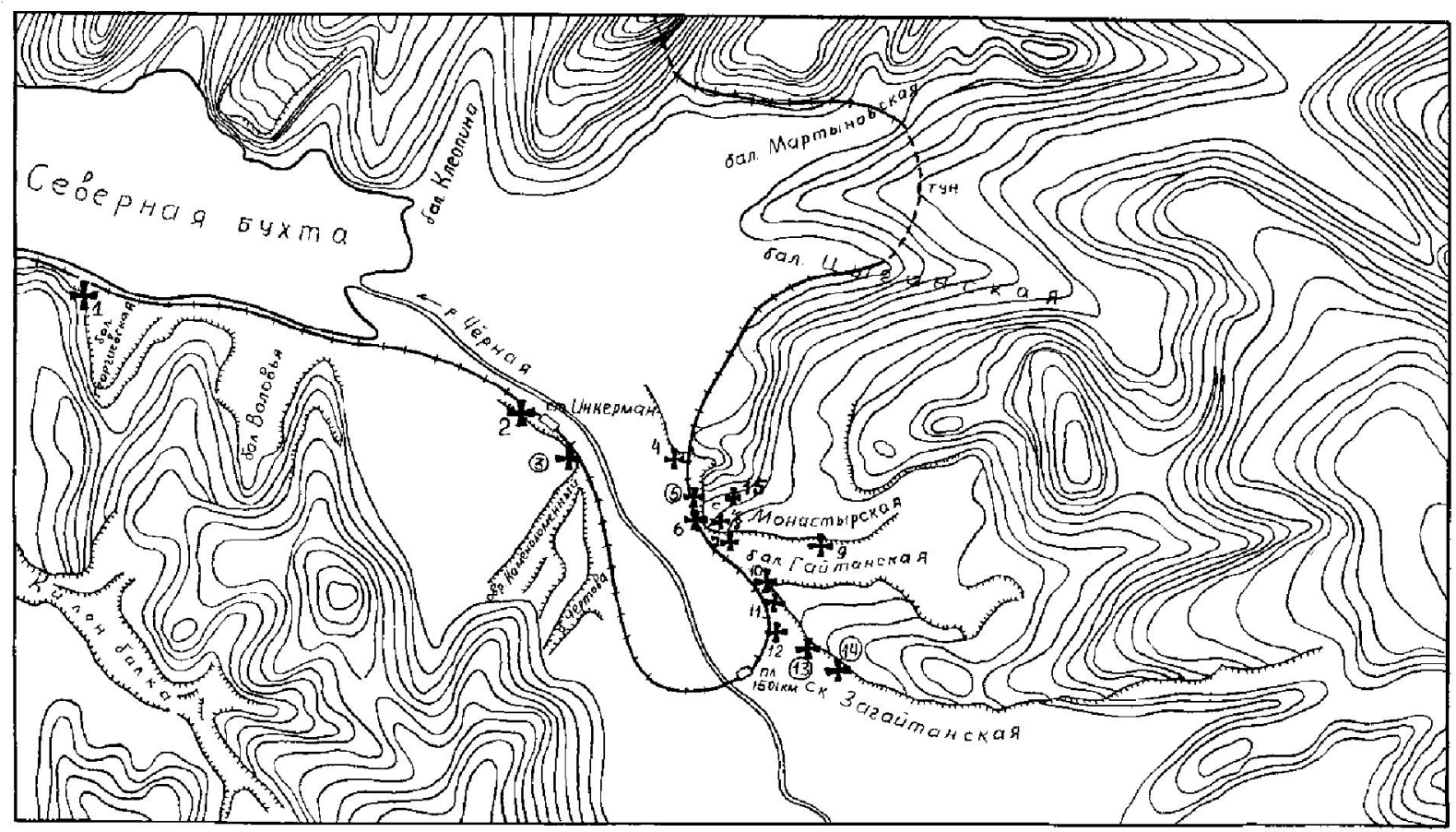

(3)- компексы цернвеи

Рис. 1. План-схема расположения пещерных церквей в Инкермане:

1 - скит в Георгиевской (Крымской) балке; 2 - скит у ст. Инкерман 1; 3 - монастырь св. Софии; 4 - «Армянский храм»; 5 - монастырь св. Климента; 6 - «Жилище архимандрита»; 7 - «Храм с крещальней»; 8 - предполагаемая церковь в комплексе «Анфилады»; 9 - «Храм География (Евграфия)»; 10-11 - монастырь на юго-западном краю Загайтанской скалы;

12-14 - монастырь в восточной части Загайтанской скалы; 15 - церковь в крепостном рву Каламиты

Fig. 1. Plan of Inkerman indicating the location of cave churches:

1 - Hermitage in Georgievskaya (Crimean) wash; 2 - The hermitage near Inkerman station I; 3 - Monastery of St. Sofia; 4 - "Armenian Temple"; 5 - St. Clement basilica; 6 - "The dwelling of the archimandrite"; 7 - "Temple with baptistery"; 8 - The alleged church in the "Enfilade" complex; 9 - "Church of Geography (Eugraphia)"; 10-11 - Monastery on the southwestern edge of the Zagaytanskaya rock;

12-14 - Monastery in the eastern part of the Zagaytanskaya rock; 15 - Church in the moat of Kalamita 
Ю.М. Могаричев, А.С. Ергина. Утраченные фресковые росписи пещерных церквей Инкермана

ПЛ АН

ПЕЩЕРНОГО ХРАМА С КРЕЩАЛЬНЕН В ЮГО-ВОСТОЧНОМ ОБРЫВЕ ННКЕРМАНСКОЙ СКААЫ

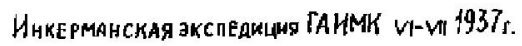

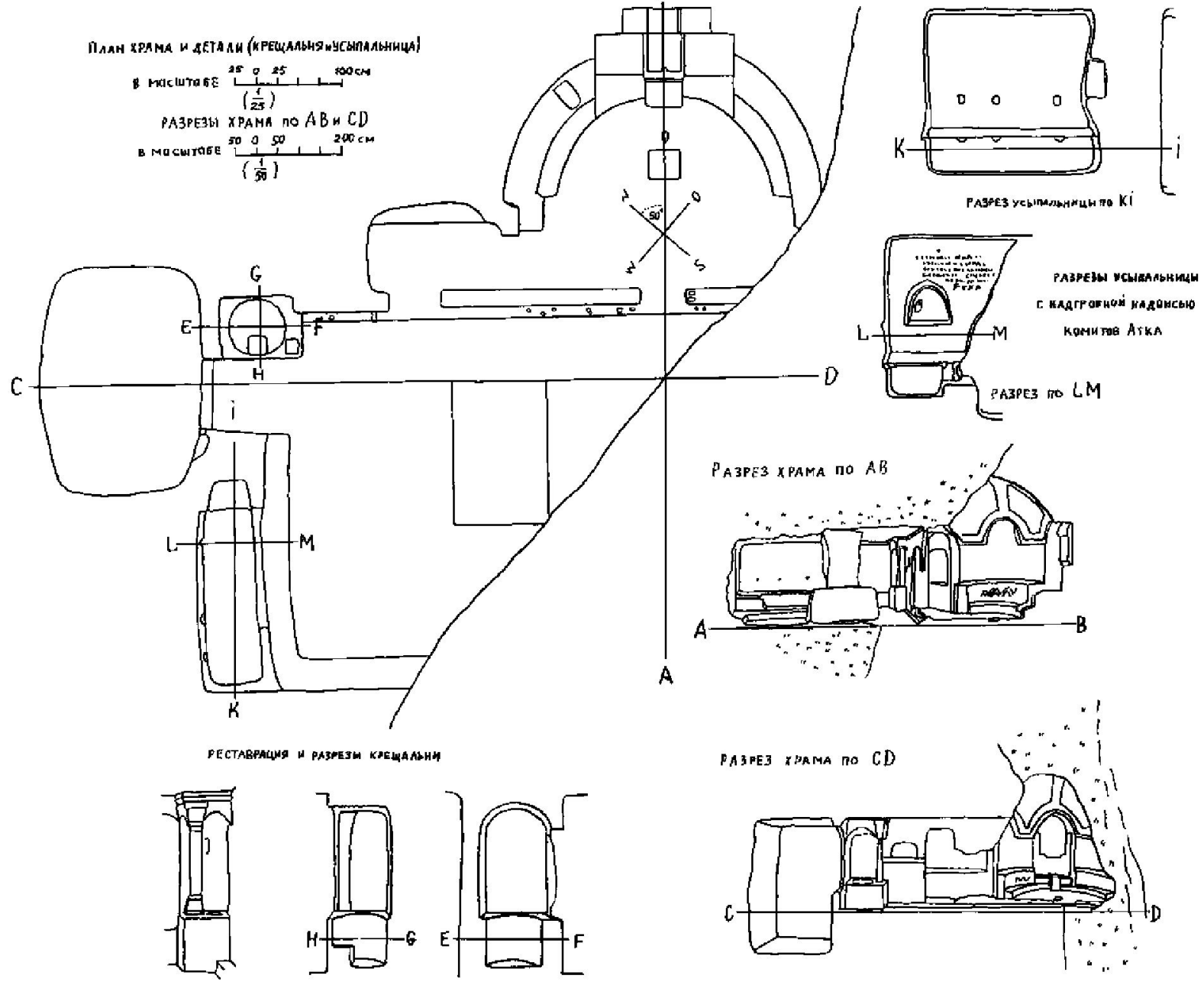

Рис. 2. «Храм с крещальней». План. Разрезы. По материалам экспедиции ГАИМК 1937 года

Fig. 2. "Temple with baptistery”. Plan. Section. GAIMK expedition materials (1937) 


\section{ВИЗАНТИЙСКАЯ ТАВРИКА}

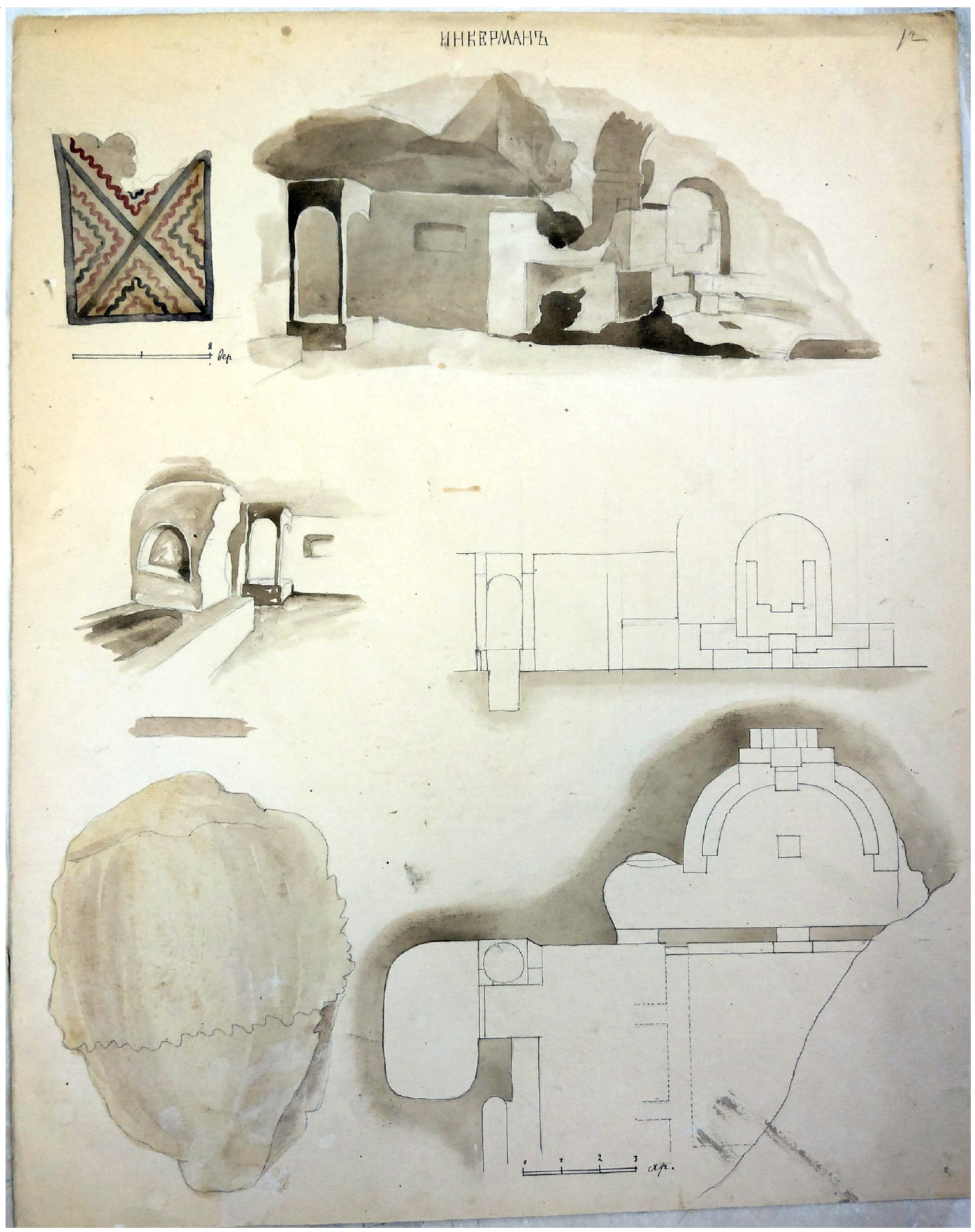

Рис. 3. «Храм с крещальней». Акварель Д.М. Струкова

Fig. 3. "Temple with baptistery". Watercolor by D.M. Strukov 
Ю.М. Могаричев, А.С. Ергина. Утраченные фресковые росписи пещерных церквей Инкермана

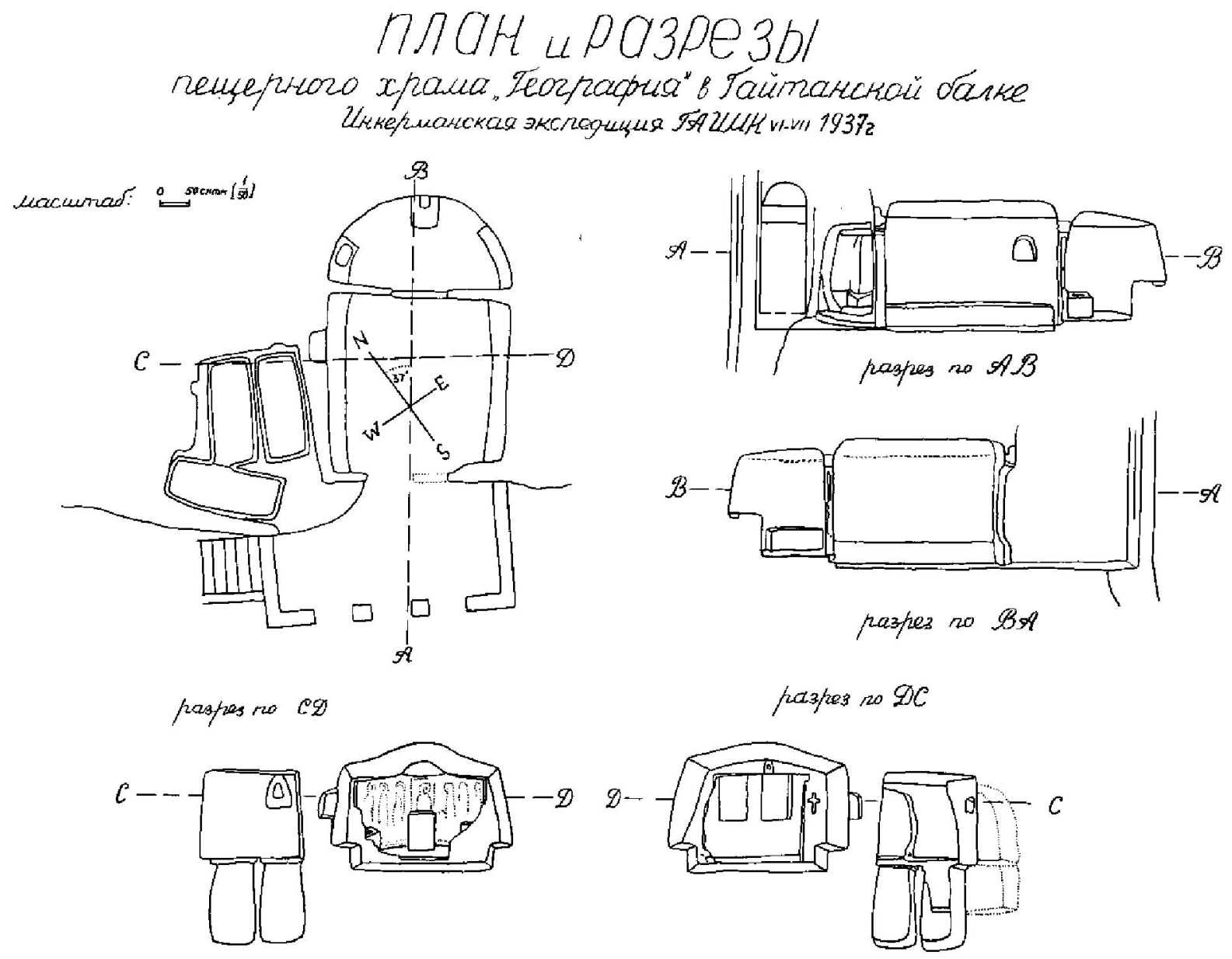

Рис. 4. «Храм География». План. Разрезы. По материалам экспедиции ГАИМК 1937 года

Fig. 4. "Church of Geography”. Plan. Section. GAIMK expedition materials (1937) 


\section{ВИЗАНТИЙСКАЯ ТАВРИКА}

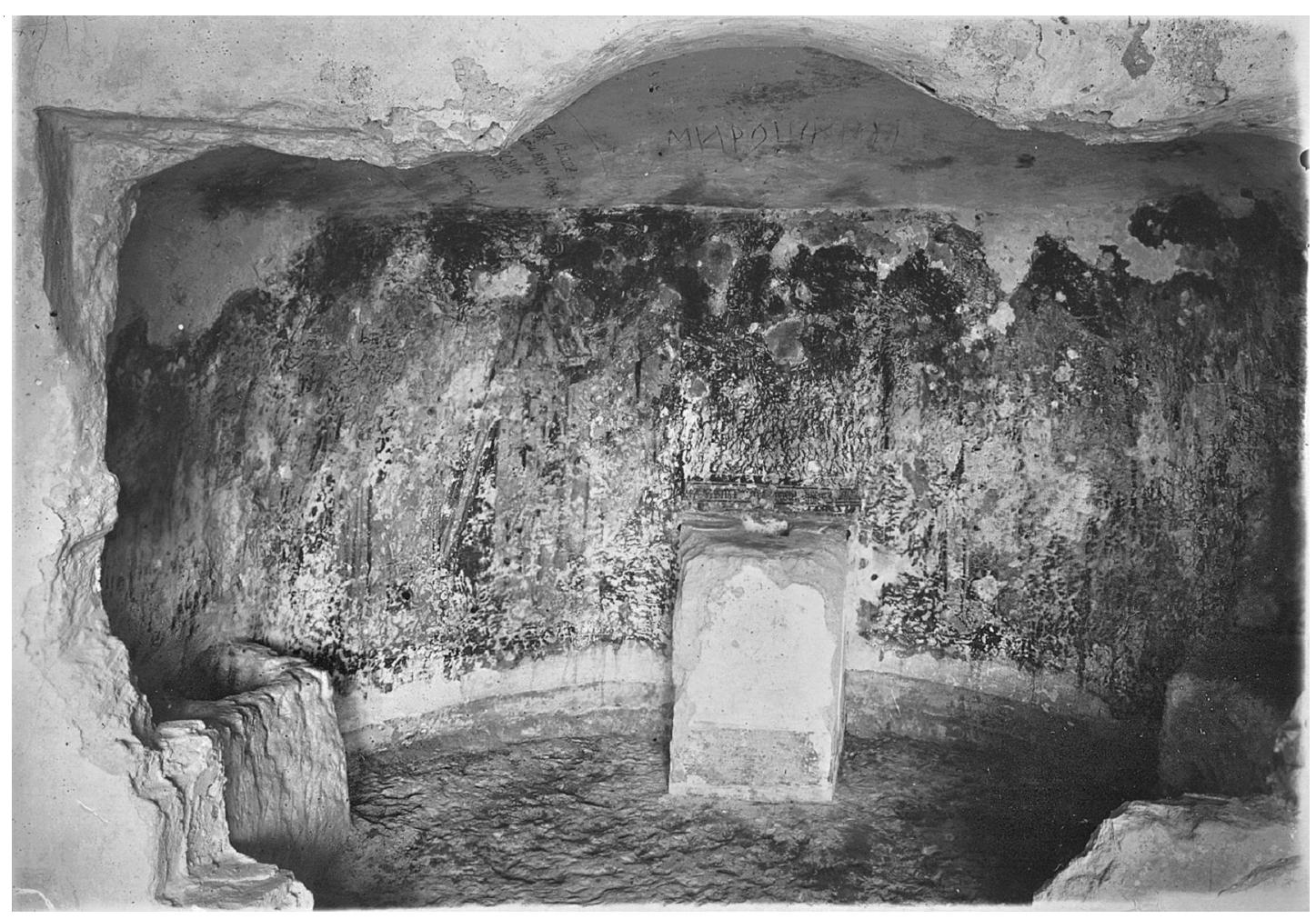

Рис. 5. «Храм География». Фото. По материалам экспедиции ГАИМК 1937 года Fig. 5. "Church of Geography". Photo. GAIMK expedition materials (1937)

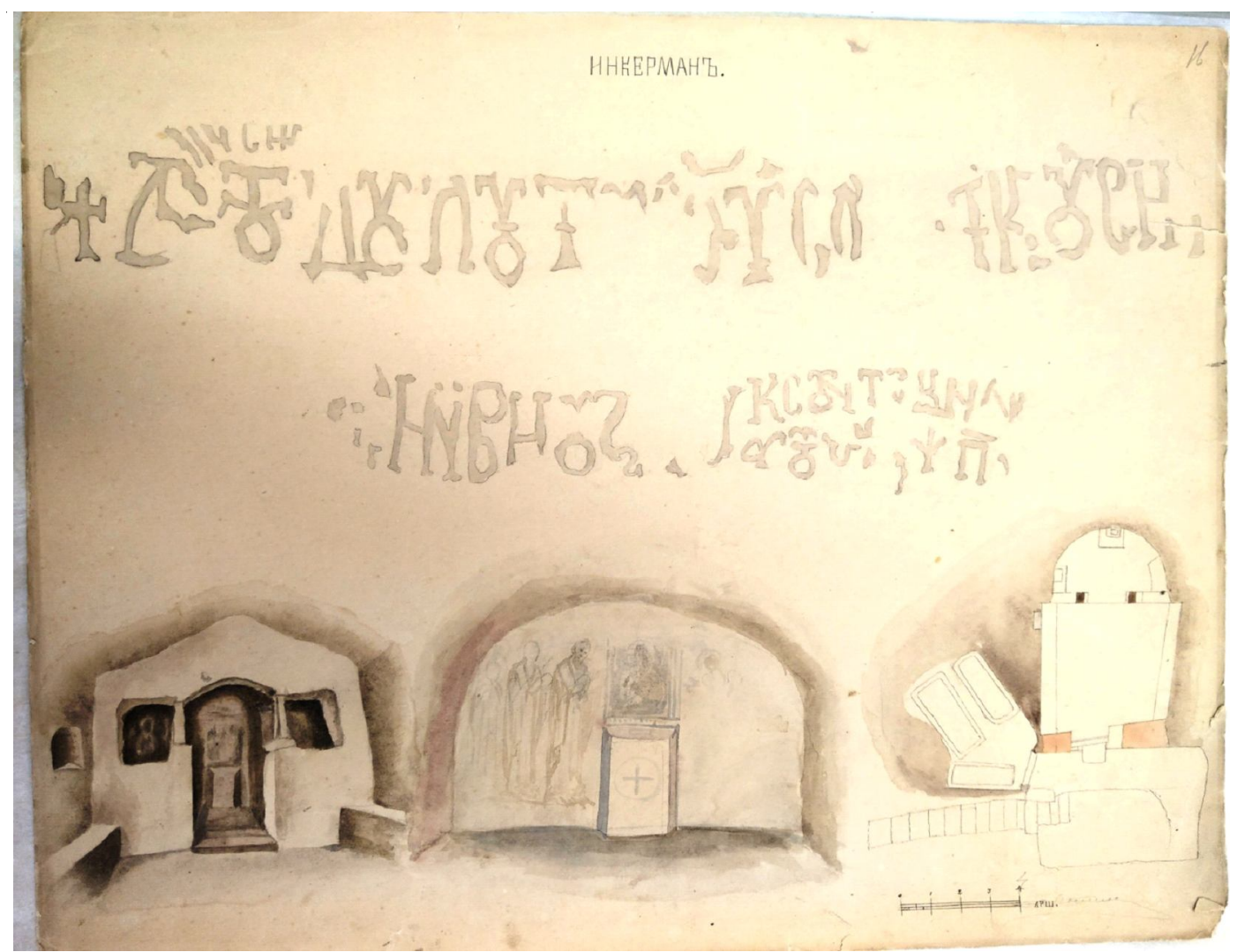

Рис. 6. «Храм География». План. Вид на алтарную часть. Копия надписи. Акварель Д.М. Струкова

Fig. 6. "Church of Geography". Plan. The altar part. Copy of the inscription. Watercolor by D.M. Strukov 
Ю.М. Могаричев, А.С. Ергина. Утраченные фресковые росписи пещерных церквей Инкермана

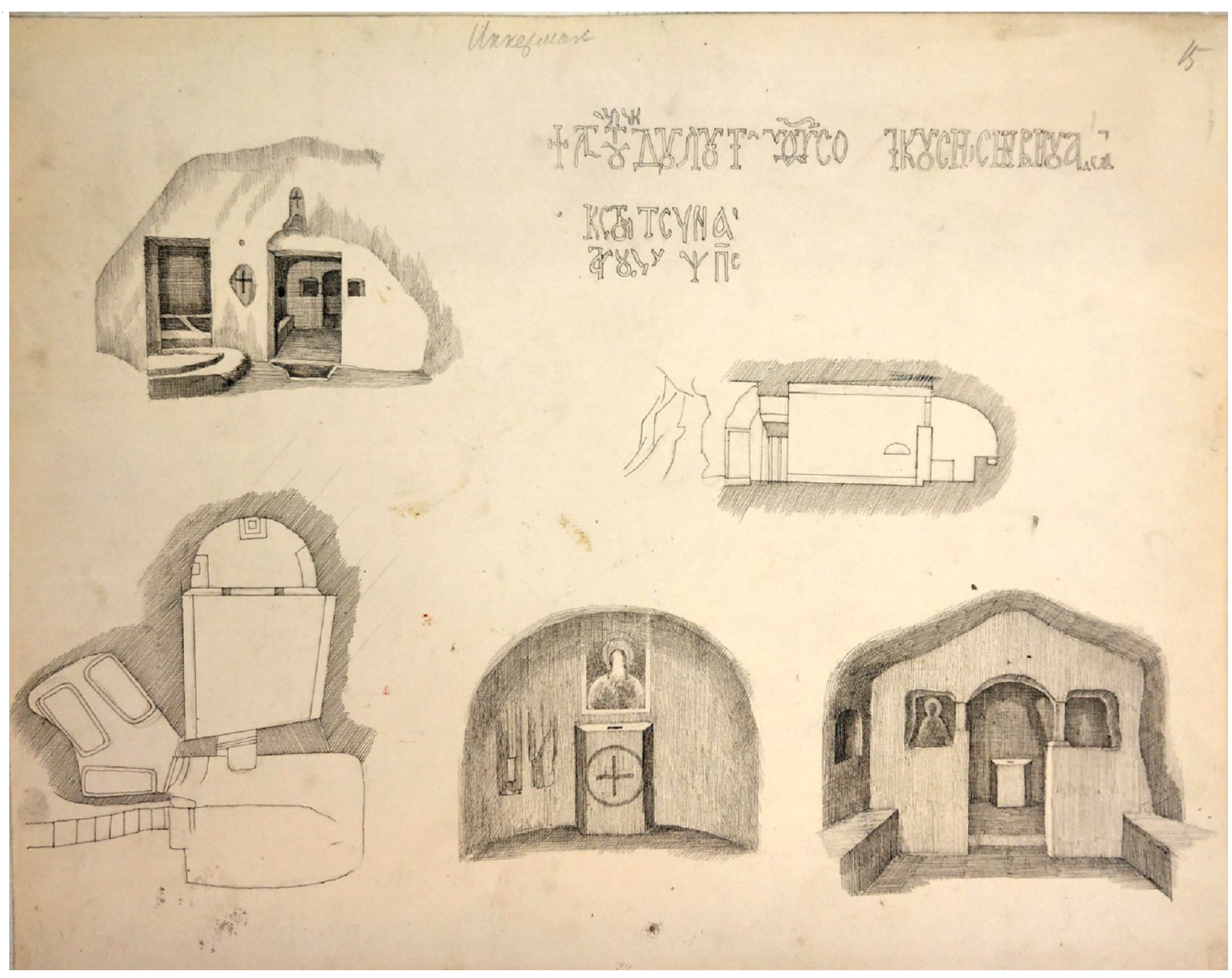

Рис. 7. «Храм География». План. Разрезы. Внешний вид. Вид на алтарную часть. Копия надписи. Акварель Д.М. Струкова

Fig. 7. "Church of Geography". Plan. Cuts. Appearance. The altar part. Copy of the inscription. Watercolor by D.M. Strukov 


\section{ВИЗАНТИЙСКАЯ ТАВРИКА}

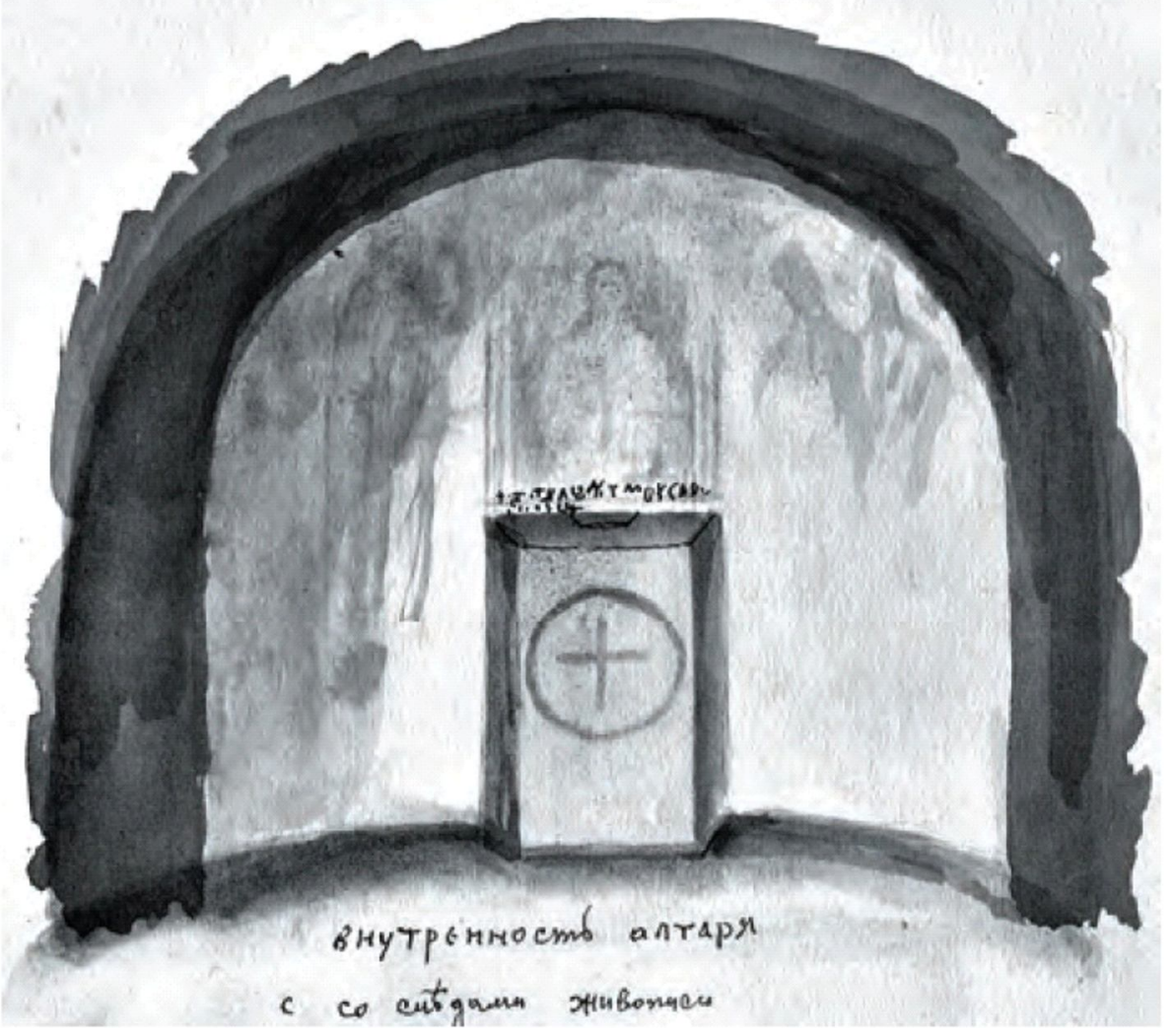

Рис. 8. «Храм География». Алтарная часть. Рисунок Д.М. Струкова

Fig. 8. "Church of Geography". The altar part. Drawing by D.M. Strukov

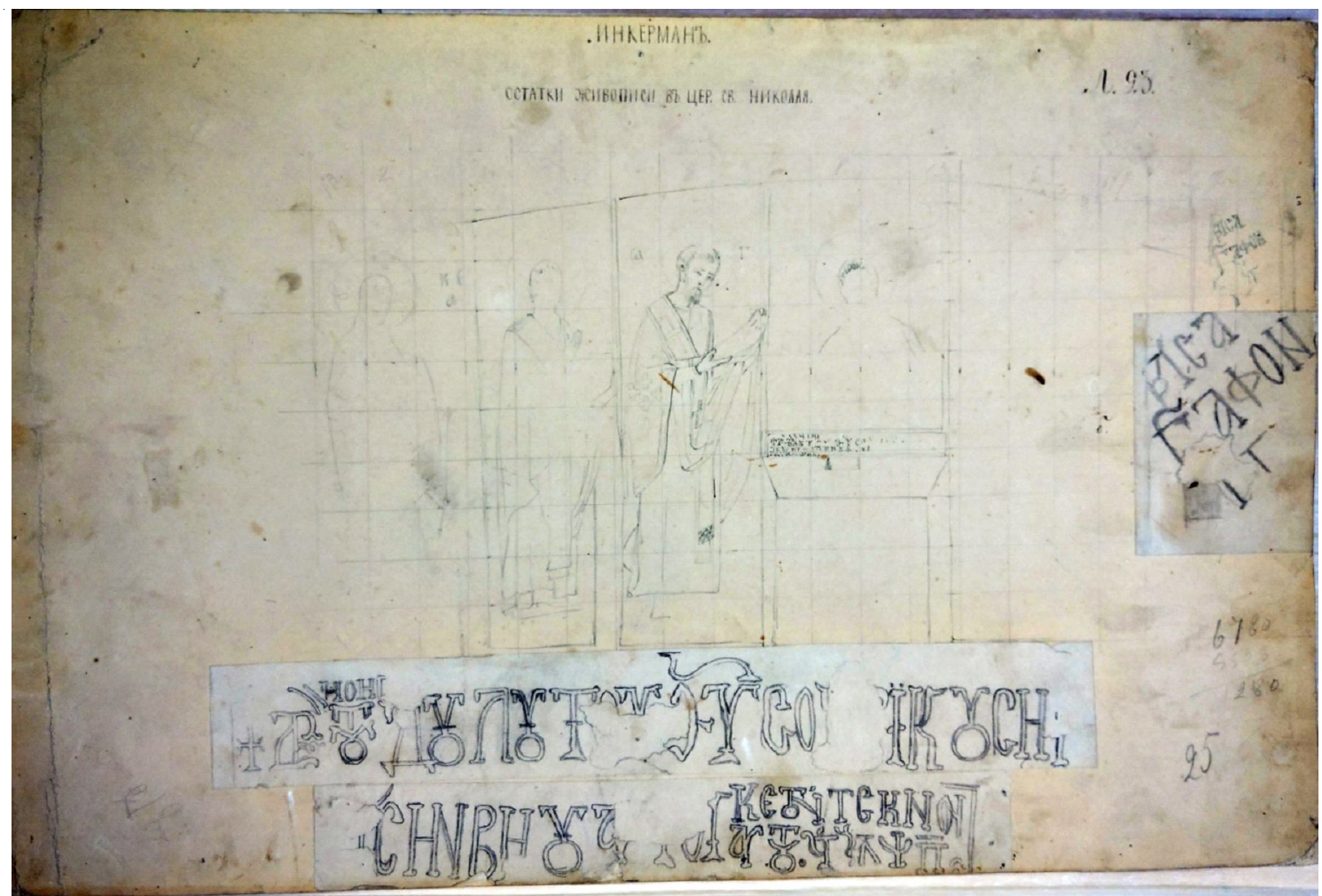

Рис. 9. «Храм География». Фрагмент росписей. Копия надписи. Акварель Д.М. Струкова

Fig. 9. "Church of Geography”. Fragment of paintings. Copy of the inscription. Watercolor by D.M. Strukov 
Ю.М. Могаричев, А.С. Ергина. Утраченные фресковые росписи пещерных церквей Инкермана

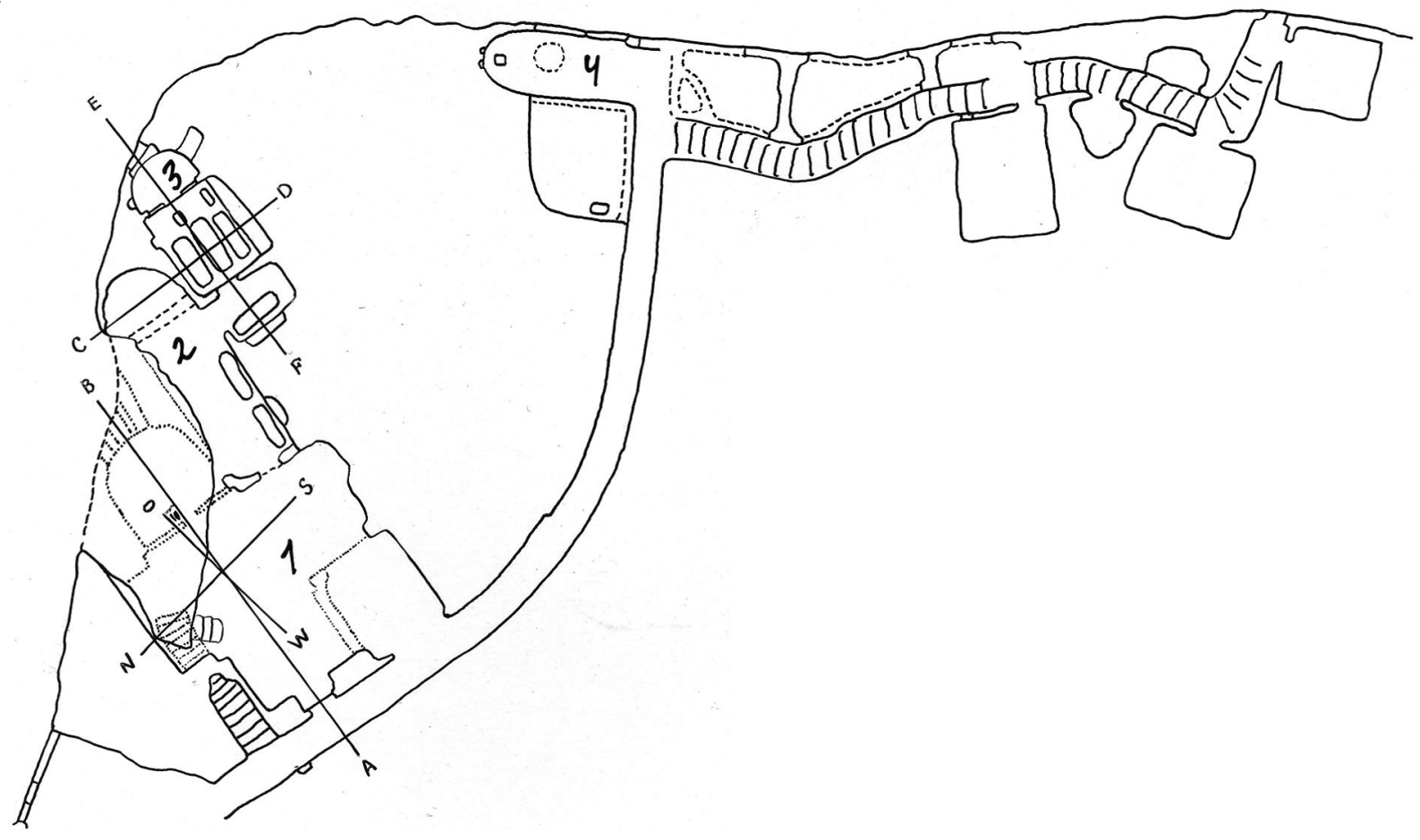

Рис. 10. Монастырь св. Софии. План. 1, 2... - номера церквей

Fig. 10. Monastery of St. Sofia. Plan. 1, 2..- the numbers of churches 


\section{ВИЗАНТИЙСКАЯ ТАВРИКА}

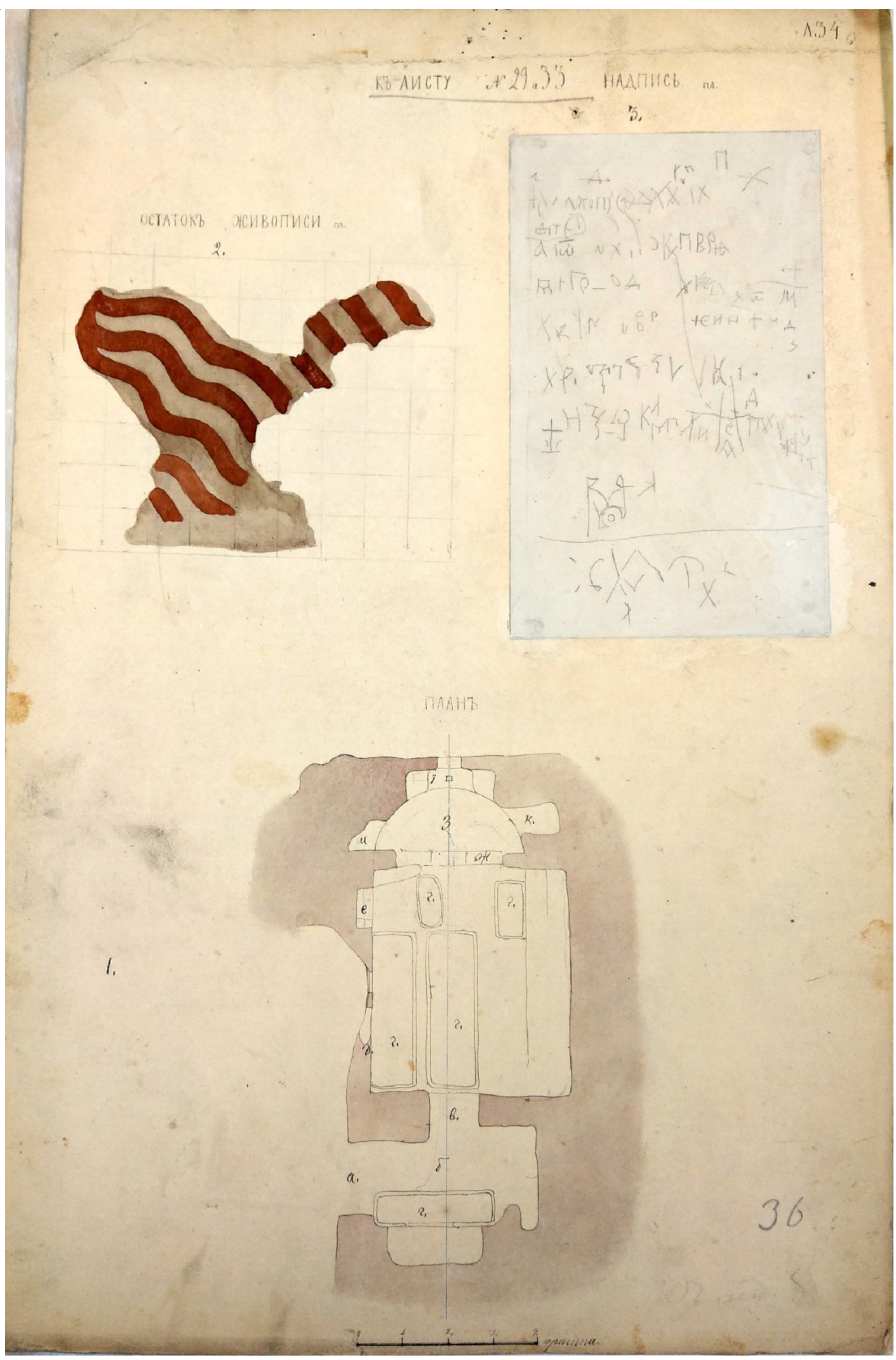

Рис. 11. Монастырь св. Софии. План церкви № 3. Фрагменты росписи. Копии надписей. Акварель Д.М. Струкова

Fig. 11. Monastery of St. Sofia. The plan of the Church no. 3. Fragments of painting. Copies of inscriptions. Watercolor by D.M. Strukov 
Ю.М. Могаричев, А.С. Ергина. Утраченные фресковые росписи пещерных церквей Инкермана

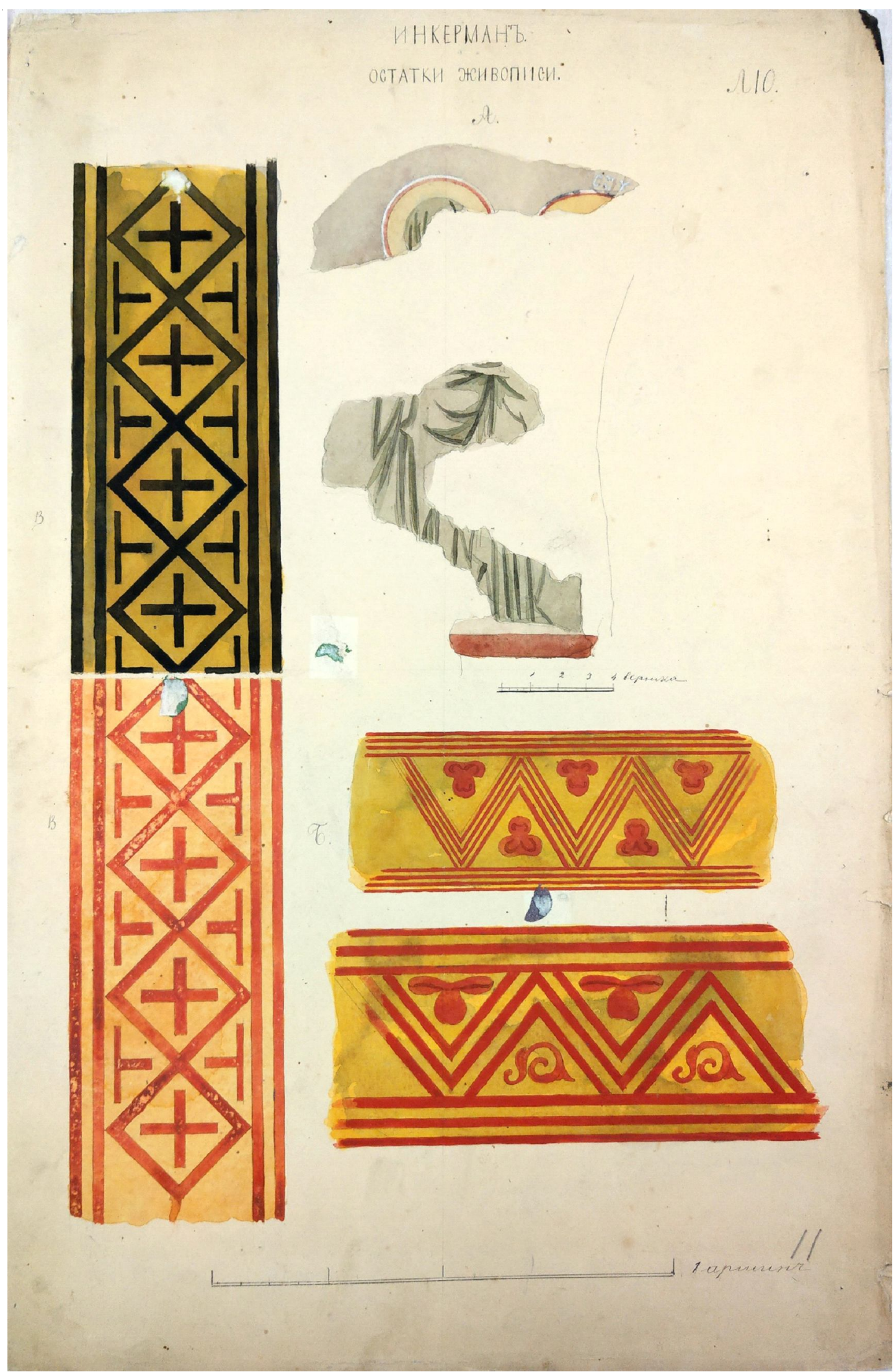

Рис. 12. Копии фрагментов орнаментов из пещерных церквей Инкермана. Акварель Д.М. Струкова Fig. 12. Cave churches of Inkerman. Fragments of ornaments. Watercolor by D.M. Strukov 


\section{СПИСОК ЛИТЕРАТУРЫ}

1. Аркас, 3. Описание Ираклийского полуострова и древностей его / 3. Аркас // Записки Одесского общества истории и древностей. $-1848 .-$ T. II, отд. 1.- С. 245-271.

2. Бертье-Делагард, А. Л. Остатки древних сооружений в окрестностях Севастополя и пещерные города Крыма / А. Л. Бертье-Делагард // Избранные труды по истории средневекового Крыма. Симферополь : Доля, 2012. - С. 7-153.

3. Бобровський, Т. А. Нововідкрита печерна церква $з$ фресками візантійського часу з ПівденоЗахідного Криму / Т. А. Бобровський, К. Е. Чуєва // Праці науково-дослідного інституту памяткоохоронних досліджень. - 2005. - Вип. 1. - С. 132-152.

4. Бобровский, Т. А. Пещерная церковь с фресками византийской эпохи в Юго-Западном Крыму / Т. А. Бобровский, Е. Е. Чуева // Материалы Международной церковно-исторической конференции «Духовное наследие Крыма» памяти преподобного Иоанна, Епископа Готфского. - Симферополь : Изд-во Симферопольской и Крымской епархии, 2006. - С. 181-223.

5. Виноградов, А. Ю. Новооткрытые греческие христианские надписи из Северного Причерноморья и вопрос о статусе пещерных обителей в Горном Крыму / А. Ю. Виноградов // Миры Визан-

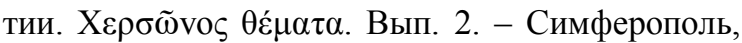
2019. - С. 331-356.

6. Виноградов, А. Ю. Каламита. Надгробие Аврамия и Космы / А. Ю. Виноградов // Византийские надписи. Древние надписи Северного Причерноморья (IOSPE). - Электрон. текстовые дан. - Режим доступа: http://iospe.kcl.ac.uk/5.151-ru.html (дата обращения: 20.05.2021). - Загл. с экрана.

7. Виноградов, А. Ю. Каламита. Посвящение Сотирика, 1272-1273 гг. / А. Ю. Виноградов // Византийские надписи. Древние надписи Северного Причерноморья (IOSPE). - Электрон. текстовые дан. Режим доступа: http://iospe.kcl.ac.uk/5.149-ru.html (дата обращения: 20.05.2021). - Загл. с экрана.

8. Герасименко, Н. В. Декорация алтарной части кафоликона монастыря Осиос Лукас / Н. В. Герасименко // Византийский временник. - 2005. Т. 64 (89). - С. 245-255.

9. Днепровский, Н. В. К вопросу о первоначальном облике пещерного храма святой Софии в Инкермане (Севастополь, АР Крым) / Н. В. Днепровский // Спелеология и спелестология : сб. материалов I Междунар. науч. заоч. конф. - Набережные Челны : Изд-во НИСПТР, 2011. - С. 147-149.

10. Днепровский, Н. В. Об одной детали литургического устройства двух пещерных церквей Инкермана / Н. В. Днепровский // Спелеология и спелестология : сб. материалов II Междунар. науч. заоч. конф. Набережные Челны : Изд-во НГПУ, 2012. - С. 137-142.
11. Днепровский, Н. В. Новые архивные материалы по инкерманскому пещерному храму «Иконописцев» («География») / Н. В. Днепровский // Спелеология и спелестология : материалы VI Междунар. науч. заоч. конф. - Набережные Челны : Изд-во НГПУ, 2015. - С. 146-154.

12. Домбровский, О. И. Фрески средневекового Крыма / О. И. Домбровский. - Киев : Изд-во АН УССР, 1966. - $110 \mathrm{c}$.

13. Дюбуа де Монпере, Ф. Путешествие в Крым / Фредерик Дюбуа де Монпере ; пер. Т. М. Фадеевой. - Симферополь : Бизнес-Информ, 2009. - 328 с.

14. Латышев, В. В. Сборник греческих надписей христианских времен из Южной России / В. В. Латышев. - СПб. : Тип. Императорской АН, 1896. - 144 с.

15. Латышев, В. В. Заметки к христианским надписям из Крыма / В. В. Латышев // Записки Одесского общества истории и древностей. - 1897. T. XX. - C. 149-162.

16. Латьшев, В. В. Заметки к христианским надписям из Крыма / В. В. Латышев // Записки Одесского общества истории и древностей. - 1898. T. XXI. - C. 225-254.

17. Могаричев, Ю. М. К дискуссии о скальной архитектуре Крыма / Ю. М. Могаричев // История и археология Юго-Западного Крыма. - Симферополь : Таврия, 1993. - С. 213-225.

18. Могаричев, Ю. М. Пещерные церкви Таврики / Ю. М. Могаричев. - Симферополь : Таврия, 1997. $-384 \mathrm{c}$.

19. Могаричев, Ю. М. «Пещерные города» в Крыму / Ю. М. Могаричев. - Симферополь : Сонат, 2005. - 192 c.

20. Могаричев, Ю. М. К вопросу о периодизации фресковых росписей пещерной церкви Южного монастыря Мангупа / Ю. М. Могаричев, А. С. Ергина // Вестник Волгоградского государственного университета. Серия 4, История. Регионоведение. Международные отношения. - 2019. - Т. 24, № 6. - С. 4763. -DOI: https://doi.org/10.15688/jvolsu4.2019.6.4.

21. Могаричев, Ю. М. Фресковые росписи пещерных георгиевских церквей Инкермана / Ю. М. Могаричев, А. С. Ергина // Византийский временник. - 2020. - Т. 104. - С. 306-331.

22. Паллас, П. С. Наблюдения, сделанные во время путешествия по южным наместничествам Русского государства в 1793-1794 годах / Петр Симон Паллас. - М. : Наука, 1999. - 248 с.

23. Репников, Н. И. Отчет Инкерманской археологической экспедиции 1937 г. / Н. И. Репников // Архив Института истории материальной культуры РАН. - Ф. 2. - Д. 227. - 87 л.

24. Репников, Н. И. Материалы к археологической карте Юго-Западного нагорья Крыма / Н. И. Репников // Архив Института истории материальной культуры РАН. - Ф. 10. - Д. 10. - 387 л. 
25. Струков, Д. М. Древние памятники христианства в Тавриде / Д. М. Струков. - М. : Универ. тип., 1876. $-51 \mathrm{c}$.

26. Струков, Д. М. Рисунки древних памятников христианства в Тавриде / Д. М. Струков // Фонд изоизданий РГБ. - Топографический шифр 105/5. - 378 л.

27. Толстой, И. И. Русские древности в памятниках искусства. Т. 4 / И. И. Толстой, Н. П. Кондаков. СПб. : Тип. М-ва путей сообщения, 1891. - 176 с.

28. Тур, В. Г. Крымские православные монастыри XIX - начала XX века. История. Правовое положение / В. Г. Тур. - Симферополь : Палитра, 1998. $-134 \mathrm{c}$.

29. Дж. Уэбстер и его вояж по Крыму в 1827 году / пер. Т. Прохоровой, О. Широкова. - Симферополь : Бизнес-Информ, 2016. - 224 с.

30. Филипенко, В. Ф. К истории Инкерманского пещерного монастыря (первый этап существования) / В. Ф. Филипенко // История и археология Юго-Западного Крыма. - Симферополь : Таврия, 1993. - С. 108-125.

31. Чепелев, В. Н. Пещерный храм в Инкермане / В. Н. Чепелев // Труды этнографо-археологического музея 1-го МГУ. - 1927. - Вып. 1. - С. 43-46.

\section{REFERENCES}

1. Arkas Z. Opisanie Irakliyskogo poluostrova i drevnostey ego [Description of the Heraclius Peninsula and Its Antiquities]. Zapiski Odesskogo obshchestva istorii $i$ drevnostey [Notes of the Odessa Society of History and Antiquities], 1848, vol. 2, sect. 1, pp. 245-271.

2. Berte-Delagard A.L. Ostatki drevnikh sooruzheniy v okrestnostyakh Sevastopolya i peshchernye goroda Kryma [The Remains of Ancient Structures in the Vicinity of Sevastopol and the Cave Cities of Crimea]. Izbrannye trudy po istorii srednevekovogo Kryma [Selected Works on the History of Medieval Crimea]. Simferopol, Dolya Publ., 2012, pp. 7-153.

3. Bobrovskiy T.A., Chuyeva K.E. Novovidkryta pecherna tserkva $\mathrm{z}$ freskami vizantiiskogo chasu $\mathrm{z}$ Pivdeno-Zakhidnogo Krymu [Newly Opened Cave Church with Frescoes of the Byzantine Period from Southwestern Crimea]. Pratsi naukovo-doslidnogo institutu pamyatkookhoronnykh doslidzhen [Proceedings of the Research Institute of Monument Protection Research], 2005, iss. 1, pp. 132-152.

4. Bobrovskiy T.A., Chueva E.E. Peshchernaya tserkov s freskami vizantiyskoy epokhi v YugoZapadnom Krymu [Cave Church with Frescoes of the Byzantine Era in Southwestern Crimea]. Materialy Mezhdunarodnoy tserkovno-istoricheskoy konferentsii «Dukhovnoe nasledie Kryma» pamyati prepodobnogo
Ioanna, Episkopa Gotfskogo [Proceedings of the International Church-Historical Conference "Spiritual Heritage of Crimea" in Memory of the Monk John, Bishop of Gothia]. Simferopol, Izd-vo Simferopolskoy i Krymskoy eparkhii, 2006, pp. 181-223.

5. Vinogradov A.Yu. Novootkrytye grecheskie khristianskie nadpisi iz Severnogo Prichernomorya i vopros o statuse peshchernykh obiteley v Gornom Krymu [Newly Discovered Greek Christian Inscriptions from the Northern Black Sea Region and the Question of the Status of Cave Dwellings in the Mountainous Crimea]. Miry Vizantii. Chersōnos themata [Worlds of Byzantium. Chersonos themata]. Simferopol, s.n., 2019, iss. 2, pp. 331-356.

6. Vinogradov A.Yu. Kalamita. Nadgrobie Avramiya i Kosmy [Kalamita. Epitaph of Abramis and Cosmas]. Vizantiyskie nadpisi. Drevnie nadpisi Severnogo Prichernomorya (IOSPE) [Byzantine Inscriptions. Ancient Inscriptions of the Northern Black Sea Region (IOSPE)]. URL: http://iospe.kcl.ac.uk/5.151ru.html (accessed 20 May 2021).

7. Vinogradov A.Yu. Kalamita. Posvyashchenie Sotirika, 1272-1273 gg. [Kalamita. Dedication of Soterikos, 1272-1273]. Vizantiyskie nadpisi. Drevnie nadpisi Severnogo Prichernomorya (IOSPE) [Byzantine Inscriptions. Ancient Inscriptions of the Northern Black Sea Region (IOSPE)]. URL: http://iospe.kcl.ac.uk/5.149ru.html (accessed 20 May 2021).

8. Gerasimenko N.V. Dekoratsiya altarnoy chasti kafolikona monastyrya Osios Lukas [Decoration of the Altar Part of the Catholicon of the Monastery of Osios Lukas]. Vizantiiskii vremennik [Byzantina Chronika], 2005, vol. 64 (89), pp. 245-255.

9. Dneprovskiy N.V. K voprosu o pervonachalnom oblike peshchernogo khrama svyatoy Sofii v Inkermane (Sevastopol, AR Krym) [On the Question of the Original Appearance of the Cave Church of St. Sophia in Inkerman (Sevastopol, Crimea)]. Speleologiya i spelestologiya: $s b$. materialov I Mezhdunar. nauch. zaoch. konf. [Speleology and Spelestology. Collection of Materials of the $1^{\text {st }}$ International Scientific Correspondence Conference]. Naberezhnye Chelny, Izd-vo NISPTR, 2011, pp. 147-149.

10. Dneprovskiy N.V. Ob odnoy detali liturgicheskogo ustroystva dvukh peshchernykh tserkvey Inkermana [On One Detail of the Liturgical Arrangement of the Two Cave Churches of Inkerman]. Speleologiya i spelestologiya: sb. materialov II Mezhdunar. nauch. zaoch. konf. [Speleology and Spelestology. Collection of Materials of the $2^{\text {nd }}$ International Scientific Correspondence Conference]. Naberezhnye Chelny, Izd-vo NGPU, 2012, pp. 137-142.

11. Dneprovskij N.V. Novye arkhivnye materialy po inkermanskomu peshchernomu khramu «Ikonopistsev» («Geografiya») [New Archival 
Materials on the Inkerman Cave Temple "Iconographers" ("Geography")]. Speleologiya $i$ spelestologiya: materialy VI Mezhdunar. nauch. zaoch. konf. [Speleology and Spelestology. Proceedings of the $6^{\text {th }}$ International Scientific Virtual Conference]. Naberezhnye Chelny, Izd-vo NGPU, 2015, pp. 146-154.

12. Dombrovskiy O.I. Freski srednevekovogo Kryma [The Frescoes of Medieval Crimea]. Kiev, Izd-vo AN USSR, 1966. $110 \mathrm{p}$.

13. Dyubua de Monpere F. Puteshestvie v Krym [Journey to Crimea]. Simferopol, Biznes-Inform Publ., 2009.328 p.

14. Latyshev V.V. Sbornik grecheskikh nadpisey khristianskikh vremen iz Yuzhnoy Rossii [Collection of Greek Inscriptions of Christian Times from Southern Russia]. Saint Petersburg, Tipografiya Imperatorskoy akademii nauk, $1896.144 \mathrm{p}$.

15. Latyshev V.V. Zametki k khristianskim nadpisyam iz Kryma [Notes to Christian Inscriptions from Crimea]. Zapiski Odesskogo obshchestva istorii $i$ drevnostey [Notes of the Odessa Society of History and Antiquities], 1897, vol. 20, pp. 149-162.

16. Latyshev V.V. Zametki k khristianskim nadpisyam iz Kryma [Notes on Christian Inscriptions from Crimea]. Zapiski Odesskogo obshchestva istorii $i$ drevnostej [Notes of the Odessa Society of History and Antiquities], 1898, vol. 21, pp. 225-254.

17. Mogarichev Yu.M. K diskussii o skalnoy arkhitekture Kryma [To a Discussion About the Rocky Architecture of Crimea]. Istoriya i arheologiya YugoZapadnogo Kryma [History and Archaeology of Southwestern Crimea]. Simferopol, Tavriya Publ., 1993, pp. 213-225.

18. Mogarichev Yu.M. Peshchernye tserkvi Tavriki [The Cave Churches of Taurica]. Simferopol, Tavriya Publ., 1997. 384 p.

19. Mogarichev Yu.M. «Peshchernye goroda»v Krymu ["Cave Towns" in Crimea]. Simferopol, Sonat Publ., 2005. 192 p.

20. Mogarichev Yu.M., Ergina A.S. K voprosu o periodizatsii freskovykh rospisey peshchernoy tserkvi Yuzhnogo monastyrya Mangupa [Reassessing the Periodization of Mural Paintings in the Cave Church of the Southern Mangup Monastery]. Vestnik Volgogradskogo gosudarstvennogo universiteta. Seriya 4. Istoriya. Regionovedenie. Mezhdunarodnye otnosheniya. [Science Journal of Volgograd State University. History. Area Studies. International Relations], 2019, vol. 24, no. 6, pp. 47-63. DOI: https: //doi.org/10.15688/jvolsu4.2019.6.4.

21. Mogarichev Yu.M., Ergina A.S. Freskovye rospisi peshchernykh georgievskikh tserkvey Inkermana [Frescoes of the St. Georges' Cave Churches
(Inkerman District)]. Vizantiiskii vremennik [Byzantina Chronika], 2020, vol. 104, pp. 306-331.

22. Pallas P.S. Nablyudeniya, sdelannye vo vremya puteshestviya po yuzhnym namestnichestvam Russkogo gosudarstva v 1793-1794 godakh [Observations Made During a Trip to the Southern Governorships of the Russian State in 1793-1794]. Moscow, Nauka Publ., 1999. 248 p.

23. Repnikov N.I. Otchet Inkermanskoy arkheologicheskoy ekspeditsii $1937 \mathrm{~g}$. [Report of the Inkerman Archaeological Expedition of 1937]. Arkhiv Instituta istorii materialnoy kultury RAN [Archive of the Institute of History of Material Culture of the Russian Academy of Sciences], f. 2, d. 227, 871.

24. Repnikov N.I. Materialy k arkheologicheskoy karte Yugo-Zapadnogo nagorya Kryma [The Matters on Archeological Map of Southwest Plateau of Crimea]. Arkhiv Instituta istorii materialnoy kultury $R A N$ [Archive of the Institute of History of Material Culture of the Russian Academy of Sciences], f. 10, d. 10,3871 .

25. Strukov D.M. Drevnie pamyatniki khristianstva $v$ Tavride [Ancient Monuments of Christianity in Taurida]. Moscow, Universitetskaya tipografiya, $1876.51 \mathrm{p}$.

26. Strukov D.M. Risunki drevnikh pamyatnikov khristianstva v Tavride [Drawings of Ancient Monuments of Christianity in Taurida]. Fond izoiizdaniy RGB [Russian State Library's Art Edition Collection]. Topograficheskiy shifr 105/5, 3781.

27. Tolstoy I.I., Kondakov N.P. Russkie drevnosti v pamyatnikakh iskusstva. T. 4 [Russian Antiquities in Art Monuments. Vol. 4]. Saint Petersburg, Tipografiya Ministerstva putey soobshcheniya, $1891.176 \mathrm{p}$.

28. Tur V.G. Krymskie pravoslavnye monastyri $X I X$ - nachala XX veka. Istoriya. Pravovoe polozhenie [Crimean Orthodox Monasteries of the $19^{\text {th }}-$ Early $20^{\text {th }}$ Centuries. History. Legal Status]. Simferopol, Palitra Publ., 1998. 134 p.

29. Dzh. Uebster i ego voyazh po Krymu v 1827 godu [J. Webster and His Voyage Across the Crimea in 1827]. Simferopol, Biznes-Inform Publ., 2016. 224 p.

30. Filipenko V.F. K istorii Inkermanskogo peshchernogo monastyrya (pervyy etap sushchestvovaniya) [On the History of the Inkerman Cave Monastery (The First Stage of Its Existence)] Istoriya $i$ arkheologiya Yugo-Zapadnogo Kryma [History and Archaeology of Southwestern Crimea]. Simferopol, Tavriya Publ., 1993, pp. 108-125.

31. Chepelev V.N. Peshchernyy khram v Inkermane [Cave Temple in Inkerman] Trudy etnografoarkheologicheskogo muzeya 1-go MGU [Proceedings of the Ethnographic and Archaeological Museum of the $1^{\text {st }}$ Moscow State University], 1927, iss. 1, pp. 43-46. 


\section{Information About the Authors}

Yurii M. Mogarichev, Doctor of Sciences (History), Professor, Leading Researcher, Institute of Archaeology of Crimea of the Russian Academy of Sciences, Prosp. Akademika Vernadskogo, 2, 295007 Simferopol, Russian Federation; Head of the Humanity and Social Science Department, Crimean Republican Institute of Postgraduate Pedagogical Education, Lenina St, 15, 295000 Simferopol, Russian Federation, mogara@rambler.ru, https://orcid.org/0000-0001-6057-2316

Alena S. Ergina, Head of the Department of Postgraduate Studies, Lecturer, Department of Painting, Saint Petersburg State Academy of Arts and Design named after A.L. Stieglitz, Solyanoy Lane, 13, 191028 Saint Petersburg, Russian Federation, yergina.alyona@gmail.com, https://orcid.org/0000-0001-7988-0415

\section{Информация об авторах}

Юрий Миронович Могаричев, доктор исторических наук, профессор, ведущий научный сотрудник, Институт археологии Крыма РАН, просп. Академика Вернадского, 2, 295007 г. Симферополь, Российская Федерация; заведующий кафедрой социального и гуманитарного образования, Крымский республиканский институг постдипломного педагогического образования, ул. Ленина, 15, 295000 г. Симферополь, Российская Федерация, mogara@rambler.ru, https://orcid.org/0000-0001-6057-2316

Алена Сергеевна Ергина, заведующая отделом аспирантуры, преподаватель кафедры живописи, Санкт-Петербургская государственная художественно-промышленная академия им. А.Л. Штиглица, Соляной пер., 13, 191028 г. Санкт-Петербург, Российская Федерация, yergina.alyona@gmail.com, https://orcid.org/0000-0001-7988-0415 